\title{
Determinants of Entrepreneurial Intention of Papuan Students (A Study in Universities in Jayapura)
}

\author{
Bonifasia E. Bharanti \\ Cenderawasih University, Indonesia \\ ebonifasia@yahoo.com
}

\begin{abstract}
Independent entrepreneurs are urgently needed in developing countries such as Indonesia considering there are many educated unemployed people and limited employment, especially in formal sector, and increasing number of job seekers every year. The common phenomenon in Papua is business opportunities in the economic sector are often used by migrants who work in formal and informal sectors, while local working age Papuans, especially university graduates, are less interested to be economic agents in Papua. This study aimed to discover factors which drove and improved entrepreneurial intention of Papuan students based on their personality characteristics: self-efficacy and need for achievement; formal environmental factors such as Entrepreneurship education and socio-cultural factor which was culturallyformed gender stereotypes. The research design was explanatory research with samples collected by stratified random sampling technique and the samples were 197 students from 4 universities in Jayapura. The data collection technique used questionnaires and data was analyzed by difference test and path analysis. The research result showed (1) Female students have stronger entrepreneurial intention, motivation for achievement, and self-efficacy than male students. (2) Partially, everything had direct influence on the formation of entrepreneurial intention except for entrepreneurship education
\end{abstract}

Keywords: Entrepreneurial intention, self-efficacy, need for achievement, entrepreneurship education, gender stereotype

\section{Introduction}

Papua Province is rich in natural resources. Economic growth in Papua Province is played more by foreign investors were much engaged in mining, forestry and fisheries, while the industrial sector that absorbs labor is very limited, so that economic growth and employment are inconsistent, and the unemployment rate of graduates of all levels of education is increasing. The highness of economic growth of the province of Papua should create more jobs which can accommodate more labor spaces continue to increase. Educated unemployment problem is a problem faced by the Province of Papua. In 2006 the number of unemployed university graduates amounted to 24.038 people and increased in 2014 to 25.108 people (Papua Provincial Department of Labour, 2010). Past studies of the Uncen Economic Team (1990) showed that the interest of students to undertake entrepreneurial activities at the University of Cendrawasih, STIE Ottow and Geisler and Yapis University in Jayapura only $16.67 \%$. The low interest in entrepreneurship is unfortunate when we see the fact that the jobs opportunities do not possible to absorb all university graduates. Law no 21/ 2001 on Special Autonomy, which requires a great opportunity and empowerment for indigenous Papuans to do business in the economic sector. Seeing this opportunity then it should utilize indigenous Papuans great opportunity to become economic actors in the region, including the Papua original student which is the young generation expected to be the future backbone for the acceleration of development in Papua. Problems faced today is the low intention of entrepreneurship (entrepreneurship desires) especially among indigenous Papuan students to participate as economic actors in their own region, such as being an independent entrepreneur (self-employment).

Krueger et al. (2000) suggested that the intention of entrepreneurship has proven to be the best predictors for entrepreneurial behavior, therefore, the intention can be used as an approximation to see whether there is a person's desire for entrepreneurship (Choo \& Wong, 2006), and have a desire entrepreneurship means that a person is committed to start a new business (Krueger et al. 2000). McCelland (1971) suggested that the need for achievement is one of the psychological motives that can motivate a person to face the challenges to achieve success and excellence. Need for achievement as one of the characteristics of a person's personality 
that will encourage someone to have entrepreneurial intention (Indarti, 2004). Bandura (1997) defines selfefficacy as a person's beliefs on his ability to complete a job. According to Robbins (1998) a person with high self-efficacy feels confident whether he can do something to change the events around it; therefore, selfefficacy is one of the factors of personality that can be used as predictors of entrepreneurial intentions.

Heilman et al. (2004) argues, gender stereotypes not only explain how the nature/character of men and women (descriptive stereotypes) but also how their roles (stereotypes perspective). The creation of gender stereotypes exactly roles in association with the person's perception of entrepreneurial intentions. Numerous studies shows that the creation of gender stereotypes affects both men and women desire to get involved and pursuing entrepreneurial activities as their career choices (Gupta et al. 2005). Behariovisme as a B. F. Skinner's theory, which essentially have three basic assumptions: (1) learning is realized through changes in behavior; (2) environment can form behavior; (3), the kontiguity principle. Ajzez (1991) suggested tha the entrepreneurs can be developed and trained through education and training programs. Therefore, entrepreneurship education is important, because future employers can be found among those who are currently undergoing the process of education at the university. Goals to be achieved in this research are: (1) Determine whether there is a difference of Achievement Requirements Motivation, self efficacy and intentions of entrepreneurship among male and female students, and (2) to know the partial effect of the entrepreneurship education, achievement motivation, self-efficacy and gender roles stereotypes to the entrepreneurial intentions of indigenous Papuans students.

\section{Literature Review}

Entrepreneurship Intentions: The entrepreneurial intention concept was developed from the Theory of Planned Behavior of Ajzen (1991) as a refinement of the Theory of Reasoned Action, Year 1975.Theory of Planned Behavior expressed a desire of someone to perform a behavior is an intermediate variable that causes the pitch uncontrollably attitudes and behaviors of a variable Other (Ajzen, 1991) Theory of Planned Behavior suggests that the intention is a function of three adjustment factors: attitude toward behavior, subjective norm, and perceived behavior control. Theory of Planned Behavior, which is the parts of the larger family of intentions models, which principally created to try to explain the emergence of entrepreneurial behavior.

Figure 1: Ajzen TPB Model (1991)

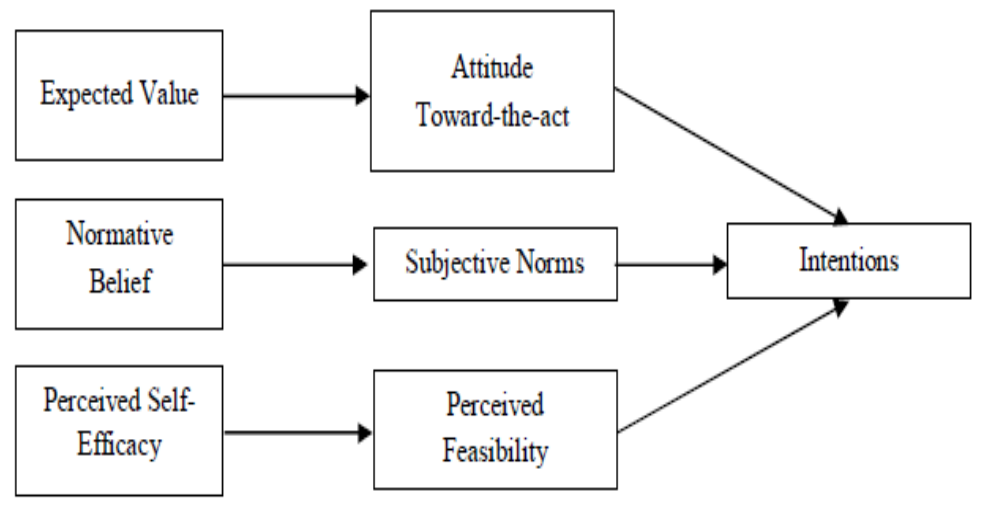

Intention model see intentions and cognitions mediate the influence of exogenous factors (demographic variables, personality characteristics, social, cultural and environmental factors) of the action and entrepreneurial behavior.

Need achievement motivation : McCelland (1971) has introduced the concept of need for achievement as one of the psychological motives. Need for achievement can be interpreted as a single character that motivates a person to respond challenges and achieve success. McCellland (1971) asserted that the need for achievement as a personality characteristic that would encourage someone to have entrepreneurial 
intentions. According to him there are four attributes attached to someone who has needs for high achievement: namely (1) like the responsibility in decision-making; (2) willing to take risks according to his ability; (3) want to do a feedback; (4) always optimistic. Collins et al. (2004) suggests the need for achievement is regarded as the most prominent predictor of student entrepreneurial intentions. Furthermore, he argues, that the need for achievement is strongly associated with entrepreneurship job options, where the individual with the needs of high achievement tend to be more interested in work that offers a higher level of control on results, personal responsibility, feedback on performance, and a high degree of risk.

Self-efficacy: According to Bandura (1997), self-efficacy is the individual beliefs regarding to the ability to perform necessary tasks or actions in order to achieve certain results. It further suggests self-efficacy to become an important contributor to form intentions and behaviors. Further it is explained that self-efficacy is not only associated with a number of skills of a person but also concerned to the confidence to do something successfully based on the capabilities for a variety of conditions. According to Bandura (1997), self-efficacy can be grown and studied through four sources of information: (1) successful experiences that occur repeatedly; (2) learning through direct observation; (3) social persuasion; (4) an assessment of the psychological status owned. According to Hisrich et al. (2008) perception of self-efficacy is associated with entrepreneurship skills. Prodan and Drnovsek (2010) entrepreneurship self-efficacy includes: (1) managerial ability: relates to the ability to define the role of the organization and manage the organization; (2) Innovation capability relates to the ability to develop and create new ideas; (3) Marketing capability relates to the ability to find information and manage the market consumer; (4) The ability in finance related to the ability to find information resources and financial management.

Role of Gender Stereotypes: The concept of gender role stereotypes is derived from the Theory of Gender Scheme. Fiedman and Shulstac (2008) argues that culture and socialization of gender roles in the culture provides gender schemes that is a variety of organized mental structure, which describes the understanding of a number of abilities, behaviors, appropriate and right situation for men and women. He argued that gender stereotypes can also predict that the individual sees himself as someone who tends to try to adapt to the traditional gender stereotypes will more often use gender schema to understand both their own behavior and others behavior. Heilman et al. (2004) suggested that gender stereotypes not only describe the characteristics of men and women based on the nature (descriptive stereotypes) but also the role they should do (stereotypical perspective). In Papua culture, generally the role of women are as follows: (1) The role of reproductive namely the role associated with pregnancy, breast-feeding, caring for and educating children (2) Role of Productive: namely as a producer of food (domestic role) and maintaining social relationships related to the position of husband socially and culturally (public role, while the role of men as the key decision makers in the family. Wigati (2008) suggested conventional imaging depicts women of Papua is a person who (1) self, (2) bold, (3) firm and (4) rigid / strong. According to the Women Study Group (1993) describes the Papuan women are (1) a hard worker; (2) persistent at work; (3) diligent worker; (4) love for work; (5) honest; (6) like to cooperate.

Entrepreneurship Education: Entrepreneurship education in this study are based on behavioral learning theory in which entrepreneurial education early given is a process that is expected to change the behavior of people towards entrepreneurial behavior. High educational environments such as universities can also write the knowledge, skills and experience required by a student associated with entrepreneurship as a provision so that later he could start effort and undergoes a career as an entrepreneur. Entrepreneurial learning according to Frazier and Niehm (2008) containing a minimum charge/elements: (1) The thought filled by entrepreneurial knowledge; (2) feeling the ups and downs of entrepreneurship and empirical experience gained from previous entrepreneurial actions; (3) entrepreneurial skills; (4) physical health, mental and social related to techniques of anticipating problems and risks; (5) direct experience. According Hansenmark (1998) entrepreneurship programs should be able to improve their knowledge, creativity, entrepreneurship skills and character formation.

Research Model Development: Dohse \& Sasca (2010) suggested an active model of entrepreneurship education (lectures, seminars, training) can directly increase entrepreneurial intentions among students. Phie 
(2009), founds that the need to learn the business and entrepreneurship through education is very important to ensure that students are able to have all the necessary ingredients to arm themselves with entrepreneurship skills. It founds that students in the program group who followed the entrepreneurship course for one semester as an elective module in their curriculum, founds that they have sensitivity which lead to a stronger entrepreneurial intention. Turker and Selcuk (2009) showed that supporting entrepreneurship education positively affects entrepreneurial intentions. Entrepreneurial education and university environment are significant predictors of entrepreneurial intentions. If a university provides enough knowledge and inspiration to entrepreneurship, the possibility to choose an entrepreneurial career can be increased among students. Past studies of Zain et al. (2010) found that personality factors based on the nature (personality traits) such as the need for achievement and self-efficacy plays an important role that affect a person's decision to entrepreneurship. Need for achievement as one of the characteristics of a person's personality that will encourage someone to have entrepreneurial intentions (Indarti and Rostiani, 2008). Entrepreneur with the need for high achievement motivation is a moderate risk taker and like things that provide precise and rapid feedback (Indarti and Rostiani, 2008).

Emmeline and Readon (2007) found a strong influence of the need for achievement motivation in the student entrepreneurship intentions in the US and Gurol and Nuray (2006) found that the need for achievement motivation to have a strong influence on the intention of entrepreneurship in Turkey. Indarti and Rostiani (2008) conducted a comparative study in three countries, namely Indonesia, Norway, and Japan. His study found no significant effect on the need for achievement on entrepreneurial intentions of students in all three countries. He said that the measure of achievement that emphasizes the success of work in the company and not become entrepreneurs is their motivation. Compared with Japan and Norway, Indonesia has a higher entrepreneurial intention scores and this is because the process of economic development is based on the emergence of new enterprises and small-scale individual supported by the government. In Japan and Norway are different, entrepreneurial activity and innovation processes is going on the great and exist company besides the perception of Japan and Norway who do not consider that their countries as a country that supports entrepreneurship so it decrease their passion for entrepreneurship. Gupta et al. (2005) found that the female stereotype has positive influence for entrepreneurial intentions. While the study of Gupta and Nachiket (2007) in the US found that gender stereotypes gives positive effect on entrepreneurial intentions. Men are more demonstrating their entrepreneurial intention compared to women in relation to their career choice.

\section{Methodology}

The population in this study were all native Papuan students scattered throughout the universities in the city of Jayapura have earned entrepreneurship education amounted to 389 students spreader across four state and private universities. Determination of the number of samples with solving formula has totaled 197 students with probability sampling with Proportional Stratified Random Sampling technique. Quality examination of the data used classical assumption (Multicollinearity normality, heterocedastity, autocorrelation) and to test the effect of each independent variable on the dependent variable used Multiple Regression formula and to see the differences in the entrepreneurship intentions and self-efficacy and need for achievement motivation between male students and female students performed different test $\mathrm{T}$ test.

\section{Results}

The assumption testing of homogeneity variance between two groups. The tools used are Levene's Test appearing that the Sig F for Levene's Test as whole is greater than 0.05 , so the assumption of homogeneity are met.

Table 1: Homogeneity testing

\begin{tabular}{lll}
\hline Variable & Levene Sig F & Conclusion \\
\hline Motivation Achievement Requirements & 0.661 & Homogent \\
Self Efficacy & 0.386 & Homogent \\
Entrepreneurship intentions & 0.963 & Homogent \\
\hline
\end{tabular}


Results of comparative analysis on testing of motivation difference of need for achievement, self-efficacy and entrepreneurial intentions in both groups of respondents, both men and women.

Table 2: Comparison Test Results between Genders

\begin{tabular}{lllll}
\hline Variabel & $\begin{array}{l}\text { Mean } \\
\text { Men }\end{array}$ & Women & Sig t & Result \\
\hline Motivation Achievement Requirements & 4.00 & 4.22 & 0.041 & Significant \\
Self Efficacy & 3.49 & 3.70 & 0.027 & Significant \\
Entrepreneurship intentions & 2.97 & 3.14 & 0.043 & Significant \\
\hline
\end{tabular}

Discussion: Based on table 4.2 above shows the need for achievement motivation and self-efficacy, so it can be concluded that there are significant differences in the motivation value of need for achievement and selfefficacy between men and women. Women have a higher need for achievement motivation and self-efficacy compared to men. This is supported by research results Mujahidin (1989) in several areas in Papua, which found that the high participation of Papua women in economic family based on the high sense of responsibility and its activities as well as the duration of work in trying to meet the needs of family life. High sense of responsibility causing them more motivated to succeed in any endeavor they do and always try to overcome the difficulties associated with his work. Women have higher self-efficacy compared to men. This suggests that confidence in the ability possessed strongly supported by their roles in big family life which is the backbone of the family to meet the economic needs of families made them confident in ability in entrepreneurship compared to men, because traditionally the role played and their daily work reflect the capabilities as implied to be a successful entrepreneur. Results show the influence of entrepreneurship education to the intention of entrepreneurship show a positive effect, but not significant. This findings show that supporting entrepreneurship education is given as lecture entrepreneurship, participation in the independent entrepreneurs program and training have not been able to raise their intentions. The existence of different findings from previous studies could be explained that the learning model applied to four colleges still use the traditional learning model that is focused on the provision of entrepreneurial knowledge without the active support of learners that have no impact on the desire for entrepreneurship.

Table 3: Analysis of Partial Results

\begin{tabular}{lllll}
\hline Relation & Coefficient & T & P & Result \\
\hline EE $\rightarrow$ EI & 0.106 & 1.496 & 0.136 & No significant \\
GS $\rightarrow$ EI & 0.513 & 8.339 & 0.000 & Significant \\
$\mathrm{NAM} \rightarrow$ EI & 0,408 & 6.07 & 0.001 & Significant \\
EF $\rightarrow$ EI & 0,394 & 5.824 & 0.000 & Significant \\
\hline
\end{tabular}

Note: $\mathrm{EE}=$ Entrepreneurship Education, GS = Gender Stereotype, EI = entrepreneurship Intention, $\mathrm{NAM}=$ Need of Achievement Motivation

Influence of gender stereotypes on entrepreneurship intentions shows the significant influence. Gender stereotypes formed on the people of Papua is still held primarily related to the division of roles between men and women in the culture of Papua. Women are more diligent in business, based on the fact that the success of the women of Papua carries out the business proved from confidence indicators of state and private banks which distribute capital credit assistance to women of Papua $60 \%$ of total loans (Voices of women of Papua, 2006). Wigati (2008) view of custom (tradition) that women do most of the aspects of life that contains, childbirth, breast-feeding, educating children (reproductive role) and fulfill the main task of the other as a producer of food by working in the garden, by the lake, and in the hamlet of sago (productive role). Men more culturally charged perform work that is of mutual aid that does not take place every day. Papuan culture that embraces the patriarchal system that still cling to the position of men as key decision makers in the family is still strong enough held. It shows that the culture of Papua, economic role of women as the primary breadwinner for the nucleus and tribal (clan) family is an important role. Hisrich and Ozturk (1999) which 
says that women in Malenesia is a producer of food. Women are the backbone of domestic life and subsistence (the backbone of the domestic life and the family breadwinner).

Need for achievement motivation effects on entrepreneurship intentions shows Papuan students in general have a high responsibility to duties, dare to risk the results of their work and have the will to always improve the results obtained. This shows that they are individuals who want troubleshooting from themselves, set goals, and strive to achieve these targets by their own efforts as proposed McClelland (1971) though people have many needs; the need for achievement is one important factor in determining the level of individual performance. Self-efficacy influences the formation of entrepreneurial intentions. It shows that students have enough confidence in their ability to achieve success and reach challenging goals such as entrepreneurship. This was proposed by Bandura (1997) He said that perceptions of self-efficacy in each individual developing from achieving gradual abilities and specific experience continuously. The ability to perceive the cognitive capabilities that bring self-confidence or stability to be used as a platform for individuals to make every effort to achieve the target set.

\section{Conclusion}

There are significant differences between men and women in relation to the need for achievement motivation, self-efficacy and entrepreneurial intentions where female has higher intense entrepreneurship, achievement motivation and self-efficacy as compared with men. Partially all give direct influences on the formation of Papuans student entrepreneurship intentions but entrepreneurship education is not a significant influence on the formation of entrepreneurial intentions.

\section{References}

Ajzen, I. (1991). The Theory of Planned Behavior. Organizational Behavior and Human Decision Processes, 50, 179-211.

Bandura, A. (1997). Self Efficacy: The Exercise of Control, W.H.Freeman and Company, New York.

Dinas Tenaga Keja Propinsi Papua. (2010). Laporan Jumlah Pencari Kerja lulusan PT. Propinsi Papua

Collins, C. J., Hanges, P. J. \& Locke, E. A. (2004). The Relation of Achievement Motivation to Entrepreneur Behavior: A Meta-Analysis. Human Performance, 17(1), 95-117.

Choo, S. \& Wong, M. (2006). Entrepreneurial Intentions: Triggers and Barrier to New Venture Creations in Singapore. Singapore Management Review, 28(2), 47-64.

Dohse, D. \& Sasca, G. W. (2010). The Role of Entrepreneurship Education and Regional Contex in Forming Entrepreneurial intentions, http: //eventosempresariales.com /aplicacio /fitxers /2010/5/Doc20101825 Juni 2010.

Emmeline, K. \& Reardon, K. (2007). The Influence of Personality Ttraits and Persuasive Messages on Entrepreneurial Intention: Across-Cultural Comparison. Career Development International, 12(4), 382-396.

Fiedman, H. S. \& Schustack, I. (2008). Theories Clasical Personality and Modern Riset, Ikarini F.D, Maria.H,;dan Andreas P.P. (Penerjemah). Kepribadian Teori Klasik dan Riset Modern, Edisi Ketiga, Penerbit Erlangga.

Frazier, B. \& Niehm, S. (2008). FCS Student Attitudes and Intentions Toward Entrepreneurial Careers. Journal of Family and Consumer Sciences, 2, 17-25.

Gurol, Y. \& Nuray, D. (2006). Entrepreneurial characteristics amongst university student: some insight for emtrepreneurship education and training in Turkey. Education and Training, 48(1), 25-38.

Gupta, K. V., Daniel, T., Arzu, W. \& Arjit, S. (2005). Entrepreneurship and Stereotype: are Entrepreneurs from Mars or from Venus? Academi of Management Best Conference Paper.

Gupta, V. \& Nachiket, B. (2007). The Influence of Proactive Personality and Stereotype Threat on Women's Entrepreneurial intentions. Journal of Leadership \& Organizational Studies, 13(4), 73-85.

Hisrich, R. \& Ozturk, S. A. (1999). Women Entrepreneurs in A Developing Economy. The Journal of Management Development, 18( 2), 114-25.

Hisrich, R., Peters, M. \& Shepherd, N. (2008). Entrepreneurship, Salemba Empat, Jakarta 
Hansenmark, O. C. (1998). The Effect of an Entrepreneurship Programme on Need for Achievement and Locus of Control of Reinforcement. International Journal of Entrepreneurial Behavior \& Research, 4(1), 2849.

Heilman, M. E., Wallen, A. S., Fuchs, D. \& Tamkins, M. M. (2004). Penalties for Success: Reaction to Women Who Succeed to Male Gender Typed Task. Journal of Applied Psychology, 89(3), 416-42.

Indarti. (2004). Factors Affecting Entrepreneurial Intentions among Indonesian Student. Jurnal Ekonomi \& Bisnis Indonesia, 19(1), 57-70

Indarti \& Rostiani. (2008). Intensi kewirausahaanMahasiswa: studi perbandingan antara Indonesia, Jepang dan Norwegia. Jurnal Ekonomi \& bIsnis Indonesia, 23(4), 369-384.

Krueger, N., Reilly, M. \& Carsrud, A. (2000). Competing Models of Entrepreneurial Intentions. Journal of business Venturing, 15, 411-432

Mujahidin, R.(1989). Peranan Sosiologi dalam Pembangunan Masyarakat Di Irian Jaya, Jayapura.

McCelland, D. (1971). The Achievement Motive in Econiomic Growth, in P Killby(ed) Entrepreneurship and Econimic Development, New york The Free Press.

Phie, Z. A. L. (2009). Entrepreneurship As a Career Choice: an Analysis of Entrepreneurial Self efficacy and Intentions of University Student. European Journal of Social Science, 9(2), 338- 346.

Prodan \& Drnovsek. (2010). Conceptualizing Academic Entrepreneurial Intentions: an Empirical Test. Tecnovation http// www.elsiever.com.

Robbins, S. P. (1998). Organizational Behavior: Concept, Controversies, pplication, Eight Editions, New Jersey, Prentice Hall International Inc.

Tim Ekonomi Uncen. (1990). Minat, Bakat, Dan Kemampuan Kewirausahaan Kalangan Mahasiswa Di Jayapura.

Turker, D. \& Selcuk, S. (2009). Which Factors Affect Entrepreneurial Intention of University Students? Journal of European Industrial Training, 3(2), 142-159

Wigati, Y. M. (2008). Helaehili dan Ehabia: Fungsinya dan Peran Perempuan salam Masyarakat Sentani Papua, Adicitra Karya Nusa, Yogyakarta

Zain, Z. M., Akram, A. M. \& Ghani, E. K. (2010). Entrepreneur intention among Malaysian business students. Canadian Social Science, 6(3), 34-44.

Instruksi Presiden .UU No 4 Tahun 1995 tanggal 30 Juni 1995. Gerakan Nasional Memasyarakatkan dan membudayakan Kewirausahaan.htpp/www.118.96.193.109/undang-undang/adm.com.

Tabloit Suara Perempuan Papua. (2006). Memberdayakan Orang Papua, Penerbit Tabloit Suara Perempuan Papua dan Institut Studi Arus Informasi, ISBN 979-8933-52-4. Jakarta.

Kelompok Studi Wanita Uncen. (1993). Perempuan dalam struktur masyarakat Dani, dan Yalli Serta Fungsinya Dalam Pengembangan Sosial Ekonomi Di Kecamatan Wamene Kota dan Kecamatan Kurima Kabupaten Dati II Jayawijaya. Laporan hasil Penelitian, Proyek Peningkatan Peranan Wanita Dalam Pembangunan Di Daerah Tingkat II Jayapura, Jayawijaya dan Sorong dengan Kelompok Studi Wanita Unicen, Jayapura. 